\title{
Comparison of Two Methods to Determine the Bending Modulus of Elasticity of Wood
}

\author{
Lucas José Marini ${ }^{1, *}$, André Luís Christoforo ${ }^{2}$, Francisco Antonio Rocco Lahr ${ }^{3}$ \\ ${ }^{1}$ Department of Materials Engineering (SMM), São Carlos School of Engineering, University of São Paulo (USP), São Carlos, SP, Brazil \\ ${ }^{2}$ Centre for Innovation and Technology in Composites (CITeC), Department of Civil Engineering (DECiv), Federal University of São \\ Carlos (UFSCar), São Carlos, Brazil \\ ${ }^{3}$ Department Structural Engineering (SET), São Carlos School of Engineering, University of São Paulo (USP), São Carlos, SP, Brazil
}

\begin{abstract}
The modulus of elasticity is among the main properties required for the dimensioning of a wood structure. It can be calculated using different test methods, the most commonly used are the 3 and 4 points bending tests. The Brazilian standard, ABNT NBR 7190: 1997, recommends the 3-point static bending test. Studies about the influence of testing methods to determine the bending modulus of elasticity are always relevant, since can improve its reliability. Thus, the aim of this study is to examine the bending modulus of elasticity of samples of nine Brazilian wood species: Cambará Rosa (Erisma uncinatum Warm), Caxeta (Tabebuia cassinoides), Tatajuba (Bagassa guianensis), Itaúba (Mezilaurus itauba), Branquilho (Termilalia spp), Cedro Amazonense (Cedrelinga catenaeformis Ducke), Roxinho (Peltogyne spp.), Cumaru (Dipteryx odorata) and Cambará (Gochnatia polymorpha). The results of the confidence intervals have showed that the moduli of elasticity for both test methods were equivalent at $5 \%$ significance level.
\end{abstract}

Keywords Tropical species, Bending test, 3 and 4 points, Characterization, Analysis of variance (ANOVA)

\section{Introduction}

Wood is a natural and renewable resource, used in several sectors, mainly in the construction sector as structural and finishing elements [1-4]. It is a heterogeneous material, constituted by various types of cells, with varied chemical, physical and mechanical properties [5]. In addition, wood presents good resistance/weight ratio, when compared to other materials such as steel and concrete [6].

For the rational application of this material it is important to know its physical and mechanical properties $[7,8]$. In Brazil, ABNT NBR 7190: 1997 (Design of Timber Structures) [9] provides guidelines for the design of structures and for the characterization of wood. In Appendix B: "Determination of wood properties for structural design", the standard recommends the 3-point static bending test, which is restricted to small and defect-free specimens.

Several data banks on wooden properties of different species contain mechanical characteristics of which the bending modulus of elasticity, compression, tensile, among other properties. The bending modulus of elasticity can be obtained by different test method, the more commonly used

\footnotetext{
* Corresponding author:

lucasmarini@usp.br (Lucas José Marini)

Published online at http://journal.sapub.org/ijme

Copyright (C) 2018 The Author(s). Published by Scientific \& Academic Publishing This work is licensed under the Creative Commons Attribution International License (CC BY). http://creativecommons.org/licenses/by/4.0/
}

are the 3 and 4 points bending tests $[10,11]$.

In [12] it was analysed the influence of testing methods (three and four points bending) and the moisture content to determine the bending modulus of elasticity, the limit of proportionality (LOP) and the elastic potential $\left(\mathrm{P}_{\mathrm{E}}\right)$. Results showed that the difference in the modulus of elasticity values measured in three and four points bending is statistically significantly affect by the moisture content, while the LOP and $P_{E}$ was not affected.

It was performed a study [13] to verify the influence of the length of wood specimens on the modulus of elasticity obtained in compression parallel to the grain $\left(\mathrm{E}_{\mathrm{c} 0}\right)$. It were adopted 1:3,1:4 and 1:5 ratios between the side of the cross section $(50 \mathrm{~mm})$ and the length of the specimens $(150,200$ and $250 \mathrm{~mm}$ ). The $\mathrm{E}_{\mathrm{c} 0}$ values are statistically equivalent to the $5 \%$ statistical significance level, showing that the changing the lengths of the specimens did not affect this property.

In addition another study was conducted to determine the influence of testing methods on the modulus of elasticity of the wood [11]. Based on ANBT NBR 7190:1997 and international standards, it was examined the bending modulus of elasticity of three wood species Canelão (Nectranda membranacea), Corymbia (Corymbia citriodora) and Angelim (Angelim sp). The results for Canelão and Angelim showed statistical equivalence between the methods at 5\% significance level. However, for Corymbia species, statistical differences of results for bending tests with three and four points were observed. 
Although the current Brazilian standards not addressed the four-point static bending tests, there are a number of papers that have evaluated it. In France [10] it was performed a study to make an analytic formula of a crossing coefficient between three and four point bending modulus of elasticity following the French standards. It has verified that the three points bending tests underestimated about $19 \%$ the values of modulus of elasticity relative to the four points test. However the relative difference between these two bending tests was not continuous following the wood density.

Other relevant study [14] have examined two methods of calculation to obtain the bending modulus of elasticity in wooden specimens of Paricá (Shizolobium amazonicum) with some defects created: a simplified, adapted from ABNT NBR 7190: 1997, and another based on the least square method. Results of the confidence intervals showed that de modulus of elasticity for both ways of calculation were equivalent for non-defective specimens. For the defective pieces the alternative methodology for the modulus of elasticity presented significantly different results from those of Brazilian standard adaptation.

In this context, this study aims to analyze the influence of different bending methods ( 3 and 4 load points) in the determination of longitudinal modulus of elasticity in specimens of nine Brazilian wood species.

\section{Material and Methods}

Table 1. Categorization of wood species in strength grading by Brazilian standard ABNT NBR 7190 (1997)

\begin{tabular}{cccc}
\hline Popular Name & Scientific Name & Grade & Density \\
\hline $\begin{array}{c}\text { Cambará Rosa } \\
(\mathrm{CR})\end{array}$ & Erisma uncinatum Warm & D20 & 0.68 \\
Caxeta (Cx) & Tabebuia cassinoides & D20 & 0.45 \\
Branquilho (Br) & Terminalia spp. & D30 & 0.78 \\
Cedro & & & \\
Amazonense & Cedrela spp. & D30 & 0.58 \\
(CA) & & & \\
Cambará (Cb) & Gochnatia polymorpha & D40 & 0.64 \\
Tatajuba (Ta) & Bagassa guianensis & D50 & 0.94 \\
Itaúba (It) & Mezilaurus itauba & D50 & 0.92 \\
Roxinho (Ro) & Peltogyne spp. & D60 & 0.97 \\
Cumaru (Cum) & Dipteryx odorata & D60 & 1.09 \\
\hline
\end{tabular}

This study was conducted at the Wood and Timber Structures Laboratory (LaMEM), Department of Structural Engineering (SET), São Carlos School of Engineering (EESC), University of São Paulo (USP). The analysis of variance (ANOVA) was used to investigate the influence of the testing methods (static bending at 3 and 4 points) in the determination of the modulus of elasticity considering wood species of Cambará Rosa (CR), Caxeta (Cx), Tatajuba (Ta), Itaúba (It), Branquilho (Br), Cedro Amazonense (CA), Roxinho (Ro), Cumaru (Cum) and Cambará $(\mathrm{Cb})$. It should be noted that the species of wood selected cover all strength grading (grade) of the hardwood of the Brazilian standard
ABNT NBR 7190 (1997) (Table 1), which contributes to a greater comprehension of the results obtained in the present research.

The classification of the wood in the strength grading of the Brazilian standard is made based on the characteristic value $(\mathrm{fc} 0, \mathrm{k})$ in the compressive strength parallel to the fibbers, as shown in Equation 1.

$$
f_{c 0, k}=\left(2 \cdot \frac{f_{1}+f_{2}+f_{3}+\ldots+f_{(n / 2)-1}}{(n / 2)-1}-f_{n / 2}\right) \cdot 1.10
$$

From Equation 1, $\mathrm{n}$ is the number of specimens used in the mechanical tests and $f_{i}$ consists of the strength values of the sample, and the results must be arranged in ascending order $\left(f_{1} \leq f_{2} \leq f_{3} \ldots \leq f_{n}\right)$, despising the largest value of the resistance if the number of specimens is odd and not being assumed to $f_{w k}$ value less $f_{l}$ and not less than $70 \%$ of the average value of the resistance. Twelve test specimens were fabricated from each species of wood to determine the values of the compressive strength parallel to the grain $\left(\mathrm{f}_{\mathrm{c} 0}\right)$, which resulted in 108 determinations. The apparent density is defined by the ratio between the mass $\left(\mathrm{m}_{12}\right)$ and the volume $\left(\mathrm{V}_{12}\right)$ of the wood specimens with a moisture content of $12 \%$.

Static bending tests were carried out assuming twelve specimens $(50 \times 50 \times 1150 \mathrm{~mm})$ per species, involving a total of 216 specimens. The modulus of elasticity was calculated for each specimen in two cases: a) three point model according to requirements of ABNT NBR 7190:1997 (Figure 1) and Equation 2; and b) four point models according to Figure 2 and Equation 3, adapted from the Strength of Materials and the Brazilian standard.

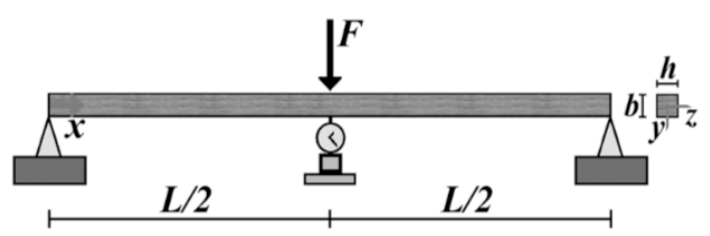

Figure 1. Three point bending tests model

$$
E=\frac{\left(F_{50 \%}-F_{10 \%}\right) \cdot L^{3}}{48 \cdot\left(\delta_{50 \%}-\delta_{10 \%}\right) \cdot I z}
$$

Where:

E: modulus of elasticity, in MPa;

F50\%: force corresponding to $50.0 \%$ of the maximum loading $\mathrm{F}$ applied to specimen, in $\mathrm{N}$;

F10\%: force corresponding to $10.0 \%$ of the maximum loading $\mathrm{F}$ applied to specimen, in $\mathrm{N}$;

$\delta 50 \%$ : is the displacement corresponding to $50.0 \%$ of the maximum loading, in $\mathrm{mm}$;

$\delta 10 \%$ : is the displacement corresponding to $10.0 \%$ of the maximum loading, in $\mathrm{mm}$;

L: span, in mm;

Iz: moment of inertia of the cross section, in $\mathrm{mm} 4$.

$$
E=\frac{23 \cdot\left(F_{50 \%}-F_{10 \%}\right) \cdot L^{3}}{648 \cdot\left(\delta_{50 \%}-\delta_{10 \%}\right) \cdot I z}
$$


Where:

E: modulus of elasticity, in $\mathrm{MPa}$;

F50\%: force corresponding to $50.0 \%$ of the maximum loading $\mathrm{F}$ applied to specimen, in $\mathrm{N}$;

F10\%: force corresponding to $10.0 \%$ of the maximum loading $\mathrm{F}$ applied to specimen, in $\mathrm{N}$;

$\delta 50 \%$ : is the displacement corresponding to $50.0 \%$ of the maximum loading, in $\mathrm{mm}$;

$\delta 10 \%$ : is the displacement corresponding to $10.0 \%$ of the maximum loading, in $\mathrm{mm}$;

$\mathrm{L}: \mathrm{span}$, in $\mathrm{mm}$;

Iz: moment of inertia of the cross section, in $\mathrm{mm} 4$.

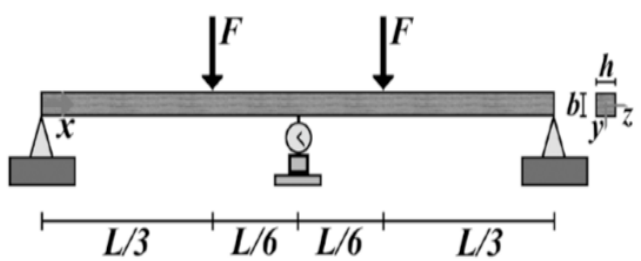

Figure 2. Four point bending tests model

The ANOVA was evaluated at a 5\% level of significance, and the null hypothesis formulated consisted of the equivalence of the means of the elasticity modulus by both test methods (P-value 0.05), and that of non-equivalence (P-value $<0.05$ ) as an alternative hypothesis (MONTGOMERY, 2005).

The Anderson-Darling [AD] and F-test [F] tests on residues were used to verify the normality and homogeneity of variances between treatments (ANOVA requirements). These tests were also considered at the 5\% significance level, and by the hypotheses formulated, P-value equal to or greater than the level and significance implies assuming normality and homogeneity of the residue variances, which validates the ANOVA model.

\section{Results and Discussion}

Figures 3 and 4 show the mean values, the confidence intervals (95\% confidence) and the variation coefficients (CV) of the modulus of elasticity obtained by both test methods and for each species of wood evaluated.

From Figure 3 and 4 it can be observed that coefficients of variation ranges from 6.92 to 24.42 (three points bending test) and 8.04 to 24.86 (four points bending test), especially in species of Cambará and Cumaru. Some factors such as slope of grain, density, moisture content and fungal attacks may influence the resistance of the wood to bending.

The mean value of $E_{m}$ for the specie of Cambará was superior to that determined by other author [18]. Tatajuba presented $E_{m}$ greater than those found in others studies, for properties determined with wood moisture content of $12 \%$ $[15,17,19]$.

For Roxinho the value of $\mathrm{E}_{\mathrm{m}}$ determined in this study was slightly higher than that determined by [17] and found at IPT [15]. Cumaru also presented higher value of $E_{m}$ when compared with others authors [15, 20,21]. These two species have high compressive strength parallel to the grain and high density, were the ones that presented the highest values of modulus of elasticity among the species of this study.

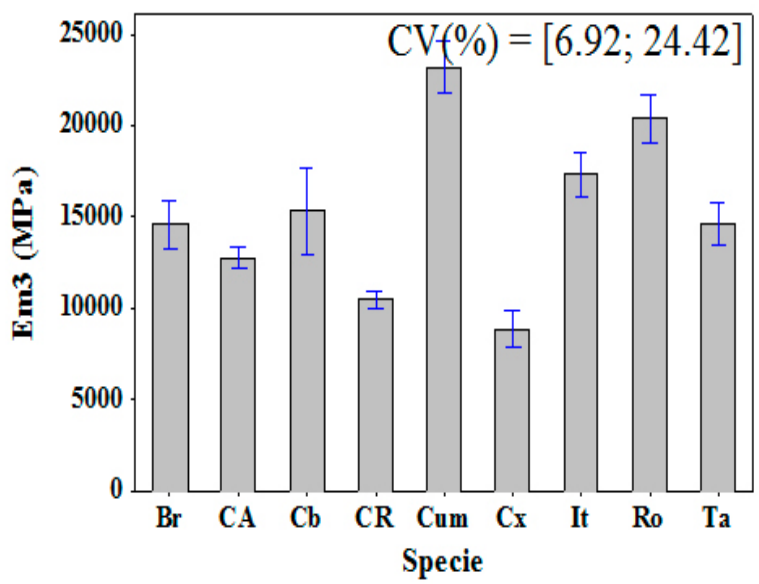

Figure 3. Elasticity modulus obtained from three points bending test

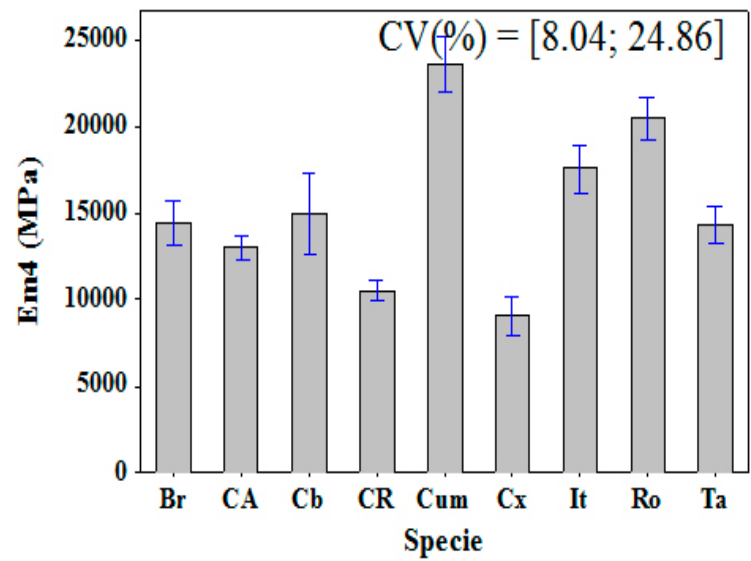

Figure 4. Elasticity modulus obtained from four points bending test

For the species of Cedro Amazonense and Itaúba the average values experimentally determined was close to those determined in others studies and by IPT $[15,20]$. Cambará Rosa presented $\mathrm{E}_{\mathrm{m}}$ compatible with that found in other works. $[15,18,20]$.

The mean values of $\mathrm{E}_{\mathrm{m}}$ determined for the Caxeta and Branquilho species were also compatible with those determined by other authors [16, 22, 23]. No information about Branquilho was found for comparison in IPT [15].

Although there are few studies on some of the species of this work, the values of $E_{m}$ found were very close to those found in the mentioned literature and also when compared to the values provided by ABNT NBR 7190: 1997 and IPT [15], potentiating both test methods for the determination of the modulus of elasticity of wood.

$\mathrm{E}_{\mathrm{m}}$ values are important for design of wooden structures. Comparing the values presented in Figure 3 with those found in Figure 4, it is observed that the variation of $E_{m}$ is insignificant. Only large differences in the $\mathrm{E}_{\mathrm{m}}$ results may cause a problem in designing structures of wood with 
rational use of the material.

Table 2 presents the ANOVA results of the test method factor on the values of the elastic moduli, and the results of the normality tests (Ander-son-Darling) and homogeneity of variances (F-test) were equal to 0.452 and 0.875 , respectively, thus validating the ANOVA model.

Table 2. Categorization of wood species in strength grading by Brazilian standard ABNT NBR 7190 (1997)

\begin{tabular}{cccccc}
\hline Source & DF & SS & MS & F & P-value \\
\hline Method (M) & 1 & 71141 & 71141 & 0.000 & 0.956 \\
Error & 214 & 4880015828 & 22803812 & & \\
Total & 215 & 4880086970 & & & \\
\hline
\end{tabular}

Where: DF - degree of freedom; SS - Sum of the squares; MS - mean squared; F - Fisher's statistic.

Since P-value (Table 2) is higher than 0.05, the equivalence between the test methods in obtaining the modulus of elasticity in static bending is verified.

\section{Conclusions}

The aim of this paper was to determine the influence of testing methods to determine the bending modulus of elasticity of nine Brazilian woods species. These species cover all strength grade of the hardwood of the Brazilian standard ABNT NBR 7190 [9]. According to the procedures adopted, it is possible to infer the following conclusions:

- For static bending tests with 3 and 4 points, results of $\mathrm{E}$ were statistically equivalent for all the nine species studied $(\mathrm{P}$-value $=0.956)$;

- It is suggested to study other species of wood and consider other moisture content values.

\section{REFERENCES}

[1] Andrade Jr, J. R.; Almeida, D. H.; Almeida, T. H.; Christoforo, A. L.; Stamato, G. C. and Lahr, F. A. R. Avaliação das estruturas de cobertura em madeira de um galpão de estoques de produtos químicos. Ambiente Construído, v.14, n.3, pp. 75-85, 2014.

[2] Obede, B. F.; Silva, D. A. L.; Rocco Lahr, F. A.; Chahud, E. and Varanda, L. D. Influence of wood moisture content on modulus of elasticity on tension parallel to the grains of Brazilian species. European International Journal of Science and Technology, n.1, pp.11-22, 2012.

[3] Cury, G. and Tomazello, M. Descrição Anatômica de Espécies de Madeira Utilizadas na Construção Civil. Floresta e Ambiente, 18(3), pp.227-236, 2011.

[4] Wieruszewski, M. and Mazela, B. Cross Laminated Timber (CLT) as an Alternative Form of Construction Wood. Drvna industrija, 68(4), pp.359-367, 2017.

[5] Guindos, P. and Ortiz, J. The utility of low-cost photogrammetry for stiffness analysis and finite-element validation of wood with knots in bending. Biosystems Engineering, 114(2), pp.86-89, 2013.

[6] Calil, C. Jr.; Lahr, F. A. R. and Dias, A. A. Dimensionamento de elementos estruturais de madeira. Barueri: Manole Ltda., 2003.

[7] Almeida, D. H.; Chahud, E.; Almeida, T. H.; Christoforo, A. L.; Branco, L. A. M. N. and Lahr, F. A R. Determination of density, shear and compression parallel to the grain strengths of Pariri (Pouteria sp.), Brazilian Native Wood specie. International Journal of Materials Engineering, v.5, n.5, pp. 109-112, 2015

[8] Carreira, M. R. and Dias A. A. Critérios para classificação de peças estruturais de Pinus Sp. Cadernos de Engenharia de Estruturas, São Carlos, v.8, n.34, pp. 17-43, 2006.

[9] Associação Brasileira De Normas Técnicas (ABNT) NBR 7190: Projeto de estruturas de madeira. Rio de Janeiro, 1997.

[10] Brancheriau, L.; Bailleres, H. and Guitard, D. Comparison between modulus of elasticity values calculated using 3 and 4 point bending tests on wooden smaples. Wood Science and Technology, 365(5), pp.367-38, 2002.

[11] Lopes, D.; Bertolini, M. S.; Christoforo, A. L. and Rocco Lahr, F. A. Influence of Testing Methods to Determine the Bending Modulus of Elasticity of Wood. Revista Vértices, 173(3), pp.127-137, 2015.

[12] Babiak, M.; Gaff, M.; Sikora A.; Hysek, S. Modulus of elasticity in three and four-point bending of wood. Composite Structures, v.204, pp.454-465, 2018.

[13] Bertolini, M. S.; Silva, D. A. L.; Souza, A. M. D.; Calil, C. and Rocco Lahr, F. A. Influência do Comprimento de Corpo de prova na Obtenção do Móodulo de Elasticidade $\mathrm{E}_{\mathrm{c} 0}$. Floresta e Ambiente, 19(2), pp.179-183, 2012.

[14] Christoforo, A. L.; Panzera, T. H.; Silva, L. J; Araújo, V. A.; Silva, D. A. L. and Rocco Lahr, F. A. Evaluation of the Modulus of Elasticity in Damaged Wooden Beams. International Journal of Materials Engineering, v.5, n.4, pp. 92-97, 2015.

[15] Instituto de Pesquisas Tecnológicas (IPT). Informações sobre madeiras. IPT 2018. Available:

https://www.ipt.br/consultas online/informacoes sobre mad eira/busca.

[16] Silva, D. A.; Lahr, F. A. R.; Faria, O. B. D. and Chahud, E. Influence of wood moisture content on the modulus of elasticity in compression to the grain. Materials Research, v.15, pp.300-304, 2012.

[17] Almeida, D. H. Estimativa de propriedades de resistência e de rigidez de madeiras tropicais brasileiras pela técnica de colorimetria. Ph. D. thesis, Dept. of Civil Engin., Univ. Federal de São Carlos. São Carlos, 2017.

[18] Lahr, F. A. R.; Arroyo, F. N.; Almeida, T. H. and Christoforo, A. L. Full Characterization of Erisma uncinatum Warm Wood Specie. International Journal of Materials Engineering, 6(5), pp. 147-150, 2016.

[19] Stangerlin, D. M.; Corassa, J. D. N.; Gatto, D. A.; Pereira, R. L. Y. and Castelo, P. A. R. Caracterização mecânica de madeiras deterioradas em campo por meio de ultrassom e flexão estática. Comunicata Scientiae, v. 6(3), pp.365-372, 2015. 
[20] Carrasco, E. V. M.; Vargas, C. B.; Souza, M. D. F. and Mantilla, J. N. R. Avaliação das características mecânicas da madeira por meio de excitação por impulso. Matéria (Rio J.) [Online], v.22, suppl.1, e.11936, 2018.

[21] Melo, J. E. D.; Souza, M; R. D. and Costa, A. F. D. Influência das dimensões dos corpos de prova e da velocidade de ensaio na resistência à flexão estática de três espécies de madeiras tropicais. Ciência Floresta, v.25 (2), pp. 415-424, 2015.
[22] Batista, A. M.; Rossi, N.; Mascia, N. T. and Furlani, J. E. Estudo de flexão estática: Relação entre peças de madeira com dimensões estruturais e dimensões reduzidas. In VII Encontro Brasileiro em Madeiras e em Estruturas de Madeiras, São Carlos, 2000.

[23] Silva, D. A.; Lahr, F. A. R.; Faria, O. B. D. and Chahud, E. Influence of wood moisture content on the modulus of elasticity in compression to the grain. Materials Research, v.15, pp.300-304, 2012. 